\title{
QUALITY OF GREYWATER IN OMAN AND ITS TREATMENT USING A SUSTAINABLE SYSTEM
}

\author{
MOHAMMED F. M. ABUSHAMMALA, WAJEEHA A. QAZI \\ \& MOHAMMED FAHAD ABDUL LATIF \\ Department of Civil Engineering, Middle East College, Sultanate of Oman
}

\begin{abstract}
Oman faces the problem of water scarcity owing to the lack of rainfall which results in lower annual replenishment rates in contrast to the consumption rates, and hence requires effective water management. Ablution greywater (AG) is a potential greywater source in Oman as it is less contaminated and discharged in huge amount from mosques. Therefore, this study assessed the quality of AG in Oman to design a sustainable multimedia (sand and activated carbon) filter for its treatment. The coconut shell activated carbon was used in the filter as it provides an inexpensive option due to the huge availability of coconut shell waste in Dhofar region in Oman. All water quality parameters of AG were acceptable as per the Omani standards, except for TSS and turbidity. When compared with past studies in Oman, it was found that the characteristics of AG significantly change with time and therefore should be continuously monitored for effective treatment. The designed multimedia filter adequately removed TSS, turbidity, $\mathrm{K}, \mathrm{BOD}_{5}, \mathrm{Na}$, and $\mathrm{Cl}$ by up to $96,96,61,50,24$, and $23 \%$, respectively. Initially the concentration of $\mathrm{NO}_{3}, \mathrm{SO}_{4}{ }^{-2}$ and $\mathrm{Mg}$ significantly increased, however, later their concentrations started reducing with time. The treatment efficiency fluctuated with time concerning TDS and $\mathrm{Ca}$. The quality of treated AG was not only in compliance with the Omani standards but also WHO guidelines to reuse wastewater for irrigation and toilet flushing. Moreover, by treating $63 \mathrm{~m}^{3}$ of water monthly, the filter can provide a yearly financial benefit of 519.14 OMR (approximately 1348.48 USD).
\end{abstract}

Keywords: wastewater, ablution greywater, activated carbon, wastewater treatment.

\section{INTRODUCTION}

In arid and semi-arid region most of the countries face the problems of water scarcity, prolonged drought and increased demand of water. Being located in this region, Oman also suffers from water shortage. The primary source of water in Oman is groundwater and due to low and highly variable rainfall it faces the tremendous deficit between replenishment and demand. The estimates show that the net annual natural replenishment of groundwater is around 1260 million cubic meters (MCM), whereas the total water demand in Oman is about $1650 \mathrm{MCM}$. This shows a deficit of $390 \mathrm{MCM}$ which the country accommodates by using groundwater reserves, consequently reducing the water tables which leads to seawater intrusions and salinization in Al Batinah coast, on which $60 \%$ of Oman's agriculture rely. The fundamental reason behind the overexploitation of groundwater resources is the perception to meet all water demands by freshwater, be it for drinking or gardening. This perception of water management needs to be changed and country should start focusing on providing sufficient amount of water with acceptable quality. In other words, Oman needs to identify alternative sources of water so as to reduce pressure on freshwater reserves [1].

Greywater originating from bath, laundry and kitchen makes up major part of domestic wastewater, and have low concentration of nutrients, organic material and pathogens [2], [3]. Another type of greywater is the water generated when worshippers perform ablution activity (washing certain body parts) in mosques before praying [3]. Previous studies show that the greywater produced from ablution ritual has even less nutrients, pathogens and organic content as compared to domestic greywater originating from bathing, washing and cooking 
[3]-[5]. According to Radin Mohamed et al. [5], Al-Wabel [6] and Abu-Rizaiza [7], the ablution greywater $(\mathrm{AG})$ has neutral $\mathrm{pH}(6.92-7.10)$ with wide variation in BOD (20-40 $\mathrm{mg} / \mathrm{l}), \mathrm{COD}(50-70 \mathrm{mg} / \mathrm{l})$, turbidity (10-30 NTU), TSS (5-146 mg/l) and E. coli (100-1000 $\mathrm{CFU} / 100 \mathrm{ml}$ ). The quality of AG clearly indicates that only a simple treatment is required to recycle it for landscaping, car washing, toilet flushing, irrigation, etc. [3], [4], [8].

Like other Middle Eastern countries, Oman also produces huge amount of greywater from ablution activity. According to Prathapar et al. [9], 1000-1500 L/day of AG is produced from a medium sized mosque in Middle Eastern countries. It is estimated that if 13,000 mosques present in Oman produce AG at the same rate, then daily around $19,500 \mathrm{~m}^{3}$ of AG is produced which is directly discharged into drainage channels without treatment. Therefore, separating AG at its source and channelling it through basic treatment to recycle for non-potable water application could result in huge amount of water and cost savings [4], [5]. Moreover, large volume of wastewater can be reduced which in turn decrease the cost of sewage treatment plant [10]. However, greywater treatment system also requires extra capital investment, operational and maintenance expenses, thus an effective treatment system based on the quality and quantity of greywater must be designed and adopted which is also financially feasible [9].

Therefore, this study attempts to design, construct and operate a sustainable low-cost multimedia filter for treating AG in Oman, and to investigate its efficiency. This study promotes the use of local and sustainable materials by using activated carbon produced from coconut shell waste, present in huge amounts in the Dhofar region in Oman, which not only saves money but also becomes a way of utilizing waste. The study also determines the change in the characteristics of AG in Oman with time by comparing with previous studies on quality of AG in Oman. Furthermore, the study discusses the capital costs involved in setting up the designed filter, operational and maintenance costs of filter, and potential water and cost savings by recycling AG from the designed system in Middle East College (MEC) mosque.

\section{METHODOLOGY}

The study was conducted at the mosque located in the campus of MEC, where the AG is discharged directly through drainage pipes into the sewage system. In order to recycle the AG, a treatment system was designed which involved a multimedia filter consisting of silica sand and activated carbon (extracted from coconut shell), as illustrated in Fig. 1. Silica sand and activated carbon were purchased from Amar Sayeed Abdullah Trading LLC and Stability Line Trading LLC, respectively. The multimedia filter was used to remove pollutants and improve the quality of AG so as to reuse it for toilet flushing and irrigation purposes. A cylindrical shaped filter made of fibre reinforced plastic (FRP) was adopted in this study with the height of $1.37 \mathrm{~m}$ and diameter of $0.25 \mathrm{~m}$. In the experimental setup, a storage tank filled with AG was connected with the filter. A pump connected to the effluent tube of storage tank pushed AG to the filtration tank to perform filtration. Filtration was carried out at a flow rate of $0.125 \mathrm{~m}^{3} / \mathrm{h}$ for 7 days because the daily average flow was $2.2 \mathrm{~m}^{3}$.

Raw AG was collected from the areas assigned to perform ablution ritual and was immediately transferred to the storage tank connected to the filter for treatment. Samples of AG before and after treatment were collected in a high density polyethylene bottle for chemical analysis and in a sterile sample bottle for microbiological testing. During the filtration period, five before and after treatment samples were collected, one each day, to investigate the quality of $\mathrm{AG}$ in terms of $\mathrm{pH}, \mathrm{BOD}_{5}, \mathrm{TSS}$, TDS, turbidity, $\mathrm{NO}_{3}, \mathrm{Cl}, \mathrm{Na}, \mathrm{Mg}$, $\mathrm{K}, \mathrm{Ca}, \mathrm{SO}_{4}^{-2}$, and E. coli. 


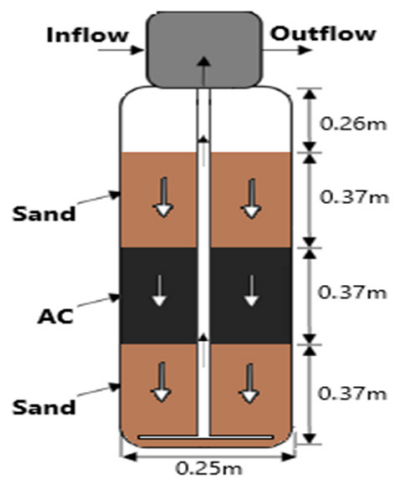

Figure 1: Multimedia filter.

\section{RESULTS AND DISCUSSIONS}

\subsection{Quality of ablution greywater and variation with time}

The results shows that $\mathrm{pH}, \mathrm{BOD}_{5}, \mathrm{TDS}, \mathrm{NO}_{3}, \mathrm{Cl}, \mathrm{Na}, \mathrm{Mg}, \mathrm{K}, \mathrm{Ca}, \mathrm{SO}_{4}^{-2}$, and $E$. coli of the generated AG are under the permissible limits set by Omani Standards (Table 1), and can be used for irrigation and toilet flushing. But the concentration of TSS exceeded the allowable limits provided by standard $\mathrm{A}^{1}$ and $\mathrm{A}^{2}$. The Omani standard for reuse of wastewater set by MD 145/1993 does not define the permissible limit for turbidity. Similarly, many countries do not have a standard for turbidity and define limit for TSS only. However, it is very important to define maximum allowable limit for turbidity as it can have a negative influence on the performance of irrigation facility, and can reduce soil's hydraulic conductivity which leads to the contamination of soil surface through surface flow. Therefore, a maximum allowable limit of 2 NTU (average) or 5 NTU set by US EPA and Saudi Standards respectively, can be adopted for reuse of treated greywater for irrigation purposes [11]. Consequently, as per the standards, it can be concluded that the quality of AG in terms of TSS and turbidity is not acceptable for reuse and require treatment before reuse.

On comparing the characteristics of AG with the quality of AG reported by Prathapar et al. [9], [12] at Sultan Qaboos University and Al Hail South mosque located in Al Khoudh and Al Hail South areas of Muscat city respectively (Fig. 2), a significant increase is observed in the concentration of TDS, $\mathrm{Cl}$ and $\mathrm{Na}$ from 2004/2005 to 2019. The highest concentration of TDS was reported in 2004 with $132 \mathrm{mg} / \mathrm{l}$ which considerably rose to $536.8 \mathrm{mg} / \mathrm{l}$ in 2019 . Similarly, an increase of $199.5 \mathrm{mg} / \mathrm{l}$ and $126.5 \mathrm{mg} / \mathrm{l} \mathrm{can}$ be seen in the concentrations of $\mathrm{Cl}$ and $\mathrm{Na}$ from 2005 to 2019, respectively. The source of freshwater for AG is groundwater, however, the increase in the concentrations of $\mathrm{Cl}$ and $\mathrm{Na}$ over the years is due to the sea water intrusion problems [13]. However, a significant decline from $58-61 \mathrm{mg} / 1$ to $1.35 \mathrm{mg} / \mathrm{l}$ is observed in the concentration of biological oxygen demand $\left(\mathrm{BOD}_{5}\right)$. Turbidity also reduced from 12.6-51 NTU in 2004/2005 to 5.06 NTU in 2019. Moreover, E. coli bacteria was totally absent in the current samples when a concentration ranging from $110 \mathrm{MPN} / 100 \mathrm{ml}$ to greater than $200 \mathrm{MPN} / 100 \mathrm{ml}$ was found in the AG in the years 2004 and 2005. These results depicts that the quality of AG significantly changed with time, hence supporting the fact presented by Prathapar et al. [14] on the variation of greywater's quality with time. Therefore, it is considered important to monitor the quality of $A G$ and update the treatment systems with time. 
Table 1: Comparison of AG quality from the current study to the previous studies.

\begin{tabular}{|c|c|c|c|c|c|c|c|c|c|c|c|}
\hline \multicolumn{2}{|c|}{ Year } & \multirow{2}{*}{\multicolumn{2}{|c|}{$\begin{array}{l}2004 \\
\text { SQU }\end{array}$}} & \multirow{2}{*}{\multicolumn{2}{|c|}{$\begin{array}{c}2004 \\
\text { Al Hail } \\
\text { South }\end{array}$}} & \multirow{2}{*}{\multicolumn{2}{|c|}{$\begin{array}{c}2005 \\
\text { Al Hail } \\
\text { South }\end{array}$}} & \multirow{2}{*}{\multicolumn{2}{|c|}{$\begin{array}{l}2019 \\
\text { MEC }\end{array}$}} & \multirow{3}{*}{$\begin{array}{c}\text { Standard } \\
\mathrm{A}^{1 \mathrm{a}}\end{array}$} & \multirow{3}{*}{$\begin{array}{c}\text { Standard } \\
\mathrm{A}^{2 \mathrm{a}}\end{array}$} \\
\hline \multirow{2}{*}{ Parameter } & \multirow{2}{*}{ Unit } & & & & & & & & & & \\
\hline & & Mean & S.D. & Mean & S.D. & Mean & S.D. & Mean & S.D. & & \\
\hline $\mathrm{pH}$ & & 7.10 & 0.24 & 7 & 1.39 & 7.20 & 0.16 & 7.39 & 0.08 & $6-9$ & $6-9$ \\
\hline $\mathrm{BOD}_{5}$ & $\mathrm{mg} / \mathrm{l}$ & 61 & 22 & 58 & 38 & - & - & 1.35 & 0.27 & 15 & 20 \\
\hline TSS & $\mathrm{mg} / \mathrm{l}$ & 25 & 22 & 34 & 15 & 9.39 & 8.20 & 35.5 & 16 & 15 & 30 \\
\hline TDS & $\mathrm{mg} / \mathrm{l}$ & 120 & 19 & 132 & 28 & 121 & 6.86 & 536.8 & 51.7 & 1500 & 2000 \\
\hline Turbidity & NTU & 34 & 17 & 51 & 36 & 12.6 & 4.20 & 5.06 & 2.24 & NA & NA \\
\hline $\mathrm{Cl}$ & $\mathrm{mg} / \mathrm{l}$ & - & - & - & - & 11.46 & 3.14 & 211 & 20.4 & 650 & 650 \\
\hline $\mathrm{Ca}$ & $\mathrm{mg} / \mathrm{l}$ & - & - & - & - & 19.13 & 1.50 & 23.38 & 10.5 & NA & NA \\
\hline $\mathrm{Mg}$ & $\mathrm{mg} / \mathrm{l}$ & - & - & - & - & 0.39 & 0.05 & 2.8 & 2.21 & 150 & 150 \\
\hline $\mathrm{Na}$ & $\mathrm{mg} / 1$ & - & - & - & - & 9.54 & 1.80 & 136 & 14.9 & 200 & 300 \\
\hline $\mathrm{K}$ & $\mathrm{mg} / 1$ & - & - & - & - & 4.76 & 0.39 & 15.9 & 4.6 & NA & NA \\
\hline $\mathrm{SO}_{4}^{-2}$ & $\mathrm{mg} / \mathrm{l}$ & - & - & - & - & 10.79 & 8.27 & 6 & 1.86 & 400 & 400 \\
\hline $\mathrm{NO}_{3}$ & $\mathrm{mg} / \mathrm{l}$ & - & - & - & - & - & - & 1.24 & 0.42 & 50 & 50 \\
\hline E.coli & $\begin{array}{l}\text { MPN/ } \\
100 \mathrm{ml}\end{array}$ & 110 & 214 & 15 & 40 & $>200$ & - & Absent & - & NA & NA \\
\hline
\end{tabular}

${ }^{\mathrm{a}}$ Omani wastewater reuse guidelines as per MD 145/1993 [15].

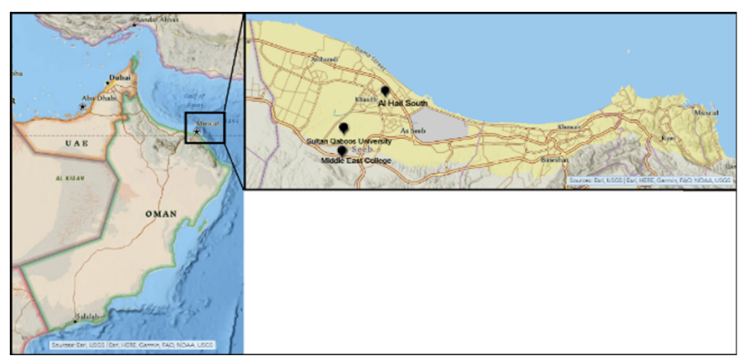

Figure 2: Map of Muscat, Oman with location of mosques.

Furthermore, in 2005, when Prathapar et al. [9] determined the characteristics of AG from Al Hail South mosque in Oman (Fig. 2), he found the quality of AG in terms of pH, COD, $\mathrm{EC}$, TSS and TDS acceptable for reuse; however, the concentration of $\mathrm{BOD}_{5}$, Coliform and $E$. coli exceeded the permissible limits. In current study, the E. coli was totally absent in the $\mathrm{AG}, \mathrm{BOD}_{5}$ was way below the acceptable limit and TSS exceeded the permissible limits, hence showing a totally opposite scenario as compared to the quality of AG back in 2005 in Oman. This also implies that the considerations for designing a treatment system changes with time as the quality of AG varies significantly.

\subsection{Quality of treated ablution greywater}

Results on the water quality of both untreated and treated AG are given in Table 2. The concentration of turbidity and TSS in AG was higher than the maximum permissible limits, however after treatment the average value of TSS and turbidity reduced to $2.86 \mathrm{mg} / 1$ and 1.48 NTU respectively, which are acceptable for irrigation and toilet flushing purposes. Other 
parameters which were acceptable even before treatment such as, $\mathrm{BOD}_{5}, \mathrm{TDS}, \mathrm{Cl}, \mathrm{Na}$ and $\mathrm{K}$ also reduced after treatment. The $E$. coli bacteria was absent in AG before and after the treatment.

Table 2: Comparison of AG before and after treatment.

\begin{tabular}{|c|c|c|c|c|c|c|c|c|}
\hline \multirow{2}{*}{ Parameter } & \multirow{2}{*}{ Unit } & \multicolumn{2}{|c|}{ Untreated } & \multicolumn{2}{|c|}{ Treated } & \multirow{2}{*}{ Standard $\mathrm{A}^{1 \mathrm{a}}$} & \multirow{2}{*}{ Standard $\mathrm{A}^{2 \mathrm{a}}$} & \multirow{2}{*}{ Acceptable } \\
\hline & & Mean & S.D. & Mean & S.D. & & & \\
\hline $\mathrm{pH}$ & & 7.39 & 0.08 & 9.1 & 0.314 & $6-9$ & $6-9$ & Yes $^{b}$ \\
\hline $\mathrm{BOD}_{5}$ & $\mathrm{mg} / \mathrm{l}$ & 1.35 & 0.27 & 0.74 & 0.134 & 15 & 20 & Yes \\
\hline TSS & $\mathrm{mg} / \mathrm{l}$ & 35.5 & 16 & 2.86 & 1.29 & 15 & 30 & Yes \\
\hline TDS & $\mathrm{mg} / \mathrm{l}$ & 536.8 & 51.7 & 520 & 20.9 & 1500 & 2000 & Yes \\
\hline $\mathrm{Cl}$ & $\mathrm{mg} / \mathrm{l}$ & 211 & 20.4 & 170.6 & 14.6 & 650 & 650 & Yes \\
\hline $\mathrm{NO}_{3}$ & $\mathrm{mg} / \mathrm{l}$ & 1.24 & 0.42 & 2.84 & 0.93 & 50 & 50 & Yes \\
\hline $\mathrm{Mg}$ & $\mathrm{mg} / \mathrm{l}$ & 2.8 & 2.21 & 19.88 & 17.32 & 150 & 150 & Yes \\
\hline $\mathrm{Na}$ & $\mathrm{mg} / \mathrm{l}$ & 136 & 14.9 & 108.8 & 10.26 & 200 & 300 & Yes \\
\hline $\mathrm{SO}_{4}^{-2}$ & $\mathrm{mg} / 1$ & 6 & 1.86 & 33.56 & 23.36 & 400 & 400 & Yes \\
\hline $\mathrm{Ca}$ & $\mathrm{mg} / \mathrm{l}$ & 23.38 & 10.5 & 28.32 & 8.52 & NA & NA & \\
\hline $\mathrm{K}$ & $\mathrm{mg} / \mathrm{l}$ & 15.9 & 4.6 & 9.46 & 4.38 & NA & NA & \\
\hline Turbidity & NTU & 5.06 & 2.24 & 1.48 & 0.85 & NA & NA & \\
\hline E.coli & $\mathrm{CFU} / 100 \mathrm{ml}$ & Absent & - & Absent & - & NA & NA & \\
\hline
\end{tabular}

${ }^{a}$ Omani wastewater reuse guidelines as per MD 145/1993 [15].

${ }^{\mathrm{b}} \mathrm{pH}$ adjustment is necessary.

After treatment the concentration of $\mathrm{Mg}, \mathrm{Ca}, \mathrm{NO}_{3}$ and $\mathrm{SO}_{4}{ }^{-2}$ increased, and the possible source for these increases is the use of sand in filter [9]. Despite increasing, the concentration of these chemical contaminants remained well below the maximum permissible levels. Furthermore, $\mathrm{pH}$ of the $\mathrm{AG}$ also increased after treatment and slightly surpassed the Omani standard threshold for irrigation. The possible reason for the increase in the $\mathrm{pH}$ could be the use of coconut shell activated carbon, as the initial effluent produced from most activated carbon products is greater than 7 . The initial spike in $\mathrm{pH}$ is believed to be due to the formation of positively charged sites on carbon during the activation process. These sites exchange anions with the influent water and raise the $\mathrm{pH}$ [16]. This can be seen as the concentration of $\mathrm{Cl}$ (anion) also reduced after treatment. Fosso-Kankeu et al. [17] and Mallongi et al. [18] also reported increase in $\mathrm{pH}$ level of the water after treatment by activated carbon media. However, this problem can be solved by controlled oxidation of activated carbon surface which stabilize the effluent $\mathrm{pH}$ by preventing ion exchange phenomenon [16]. Even though the average $\mathrm{pH}$ of treated AG just exceeded the permissible limit by 0.1 , it is necessary to adjust the $\mathrm{pH}$ before reusing it for irrigation and toilet flushing. Overall, the treated AG was found to be in compliance with the allowable limits of Omani wastewater reuse standards for irrigation and toilet flushing. Moreover, as per WHO guidelines, treated AG quality in this study is suitable for irrigation of fruit trees, fodder crops, and ornamentals.

\subsection{Efficiency of treatment unit}

The concentration of chemical contaminants in untreated and treated AG, and the removal efficiency of the treatment system are presented in Figs 3 and 4. The multimedia filter adequately removed TSS, turbidity, $\mathrm{K}, \mathrm{BOD}_{5}, \mathrm{Na}$, and $\mathrm{Cl}$ by up to $96,96,61,50,24$, and 


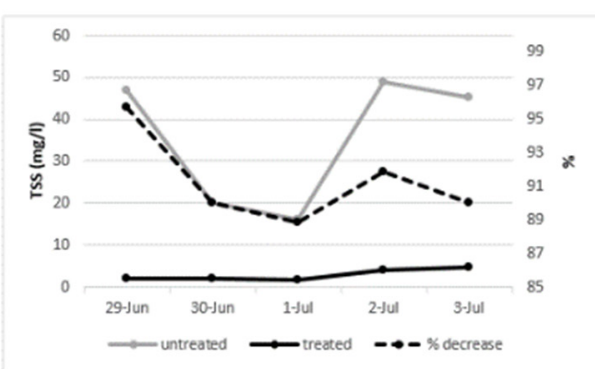

(a)

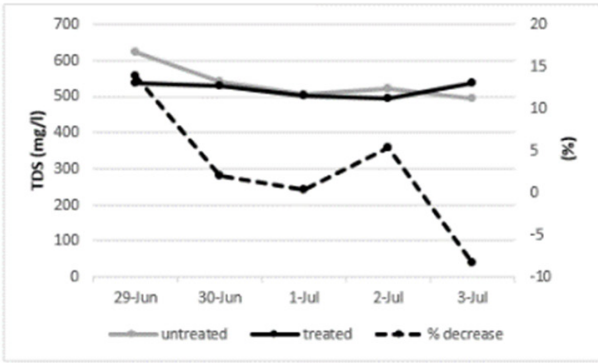

(c)

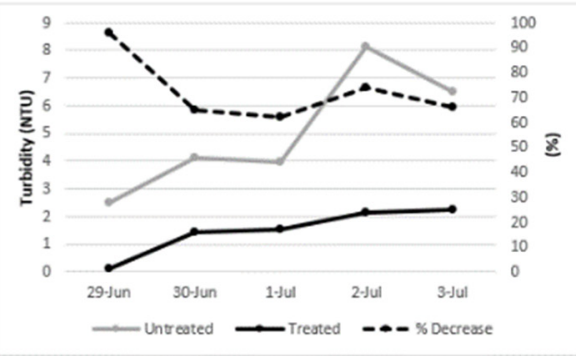

(b)

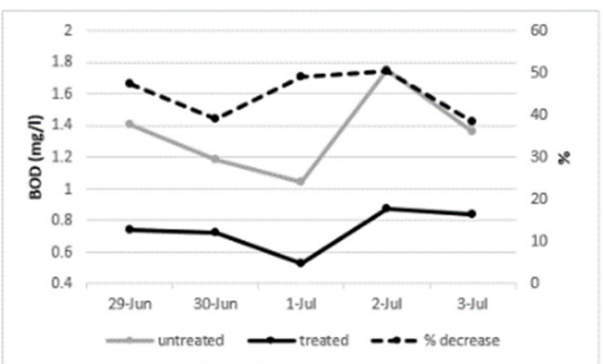

(d)

Figure 3: The concentration and removal efficiencies of (a) TSS; (b) Turbidity; (c) TDS; and $(\mathrm{d}) \mathrm{BOD}_{5}$ in untreated and treated $\mathrm{AG}$.

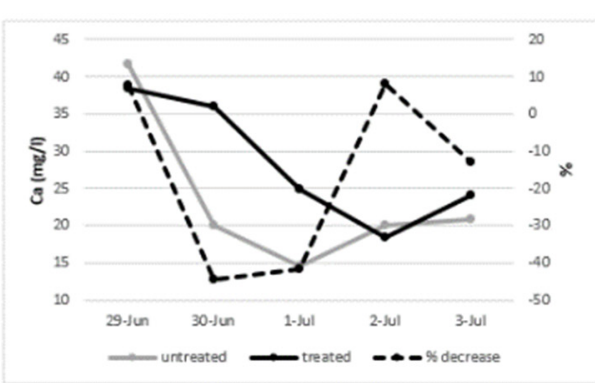

(a)

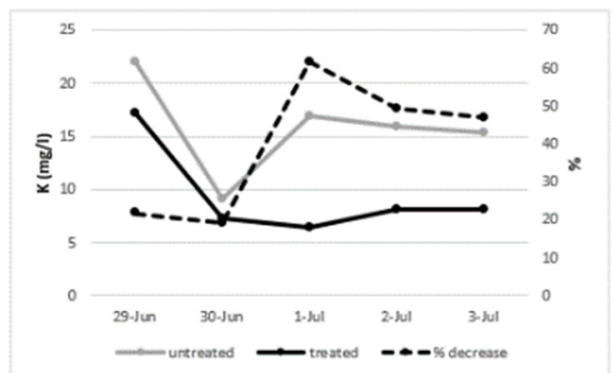

(c)

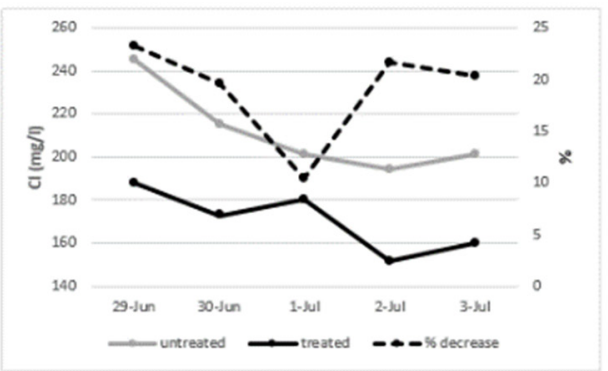

(b)

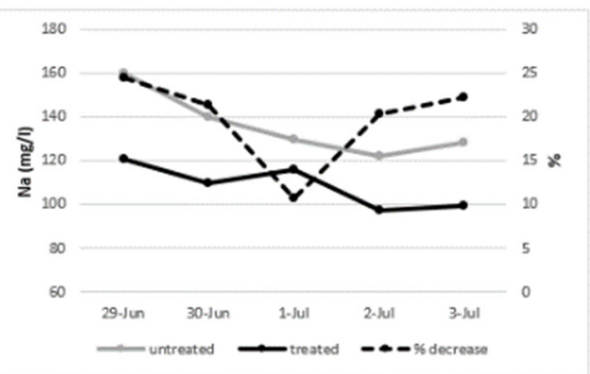

(d)

Figure 4: The concentration and removal efficiencies (a) $\mathrm{Cl}$; (b) $\mathrm{Ca}$; (c) $\mathrm{K}$; and (d) $\mathrm{Na}$ in untreated and treated AG. 
23\%, respectively (Figs 3(a), (b), and (d), and 4(b)-(d)). The removal efficiency of these parameters varied slightly with time except for $\mathrm{Cl}, \mathrm{Na}$, and $\mathrm{K}$. The removal efficiency of $\mathrm{Cl}$ and $\mathrm{Na}$ dropped to almost $10 \%$ on $1 \mathrm{July}$; on the other hand removal efficiency for $\mathrm{K}$ significantly increased from $19 \%$ on 30 June to $61 \%$ on 1 July and then slightly varied with time.

The filter achieved the removal efficiency of up to $14 \%$ for TDS, which then slightly fluctuated until 2 July before the concentration increased on 3 July by up to 8\% (Fig. 3(c)). Similarly, the change in the concentration of $\mathrm{Ca}$ in treated water fluctuated considerably with time; the filter removed the concentration up to $8 \%$ at one point and also increased the concentration of $\mathrm{Ca}$ by up to $44 \%$ (Fig. 4(a)).

The concentration of $\mathrm{SO}_{4}{ }^{-2}$ and $\mathrm{Mg}$ significantly increased by up to $92 \%$ and $99 \%$, respectively. The percent increase in the concentration of $\mathrm{SO}_{4}{ }^{-2}$ and $\mathrm{Mg}$ started reducing with time, however on 2 July the concentration of $\mathrm{SO}_{4}{ }^{-2}$ considerably increased again (Fig. 5(b) and (c)). The concentration of $\mathrm{NO}_{3}$ increased after treatment, but the percent increase in the concentration also started reducing with time (Fig. 5(d)). Prathapar et al. [9] and Al-Zu'bi et al. [10] also reported increase in the concentration of $\mathrm{Na}, \mathrm{Mg}, \mathrm{Ca}$, carbonates, sulphates, chlorides and nitrate after treating $\mathrm{AG}$. The possible reason for the increase in the concentration of $\mathrm{Mg}, \mathrm{SO}_{4}{ }^{-2}$ and $\mathrm{NO}_{3}$ could be the ion exchange phenomenon that occur in activated carbon, which resulted in the reduction of high quantities of $\mathrm{Cl}$ and increase in $\mathrm{SO}_{4}^{-}$ 2 and $\mathrm{NO}_{3}$, and decrease in the concentration of $\mathrm{Na}$ with the increase in $\mathrm{Mg}$ after treatment. Moreover, the $\mathrm{pH}$ of $\mathrm{AG}$ increased after treatment. The efficiency for $\mathrm{pH}$ slightly increased at first then remained steady with time (Fig. 5(a)).

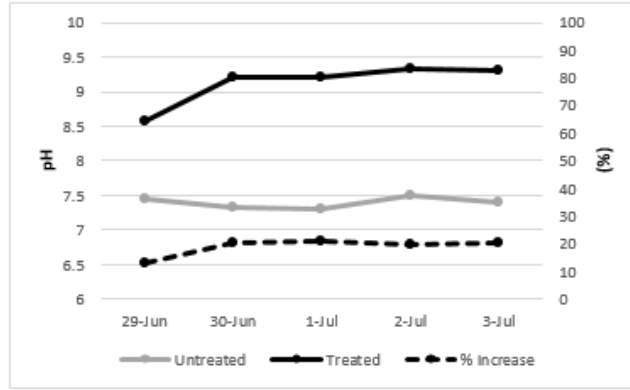

(a)

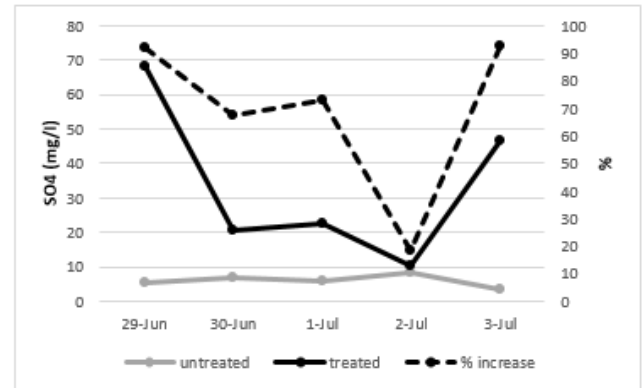

(c)

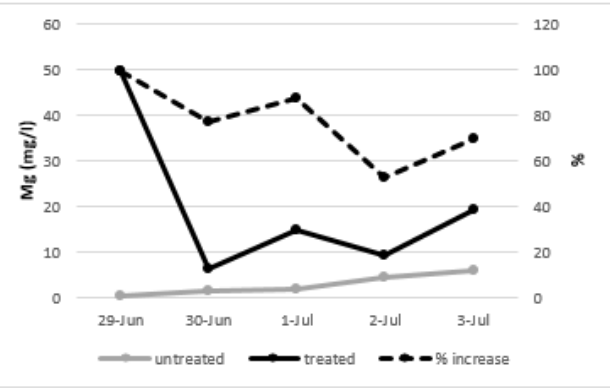

(b)

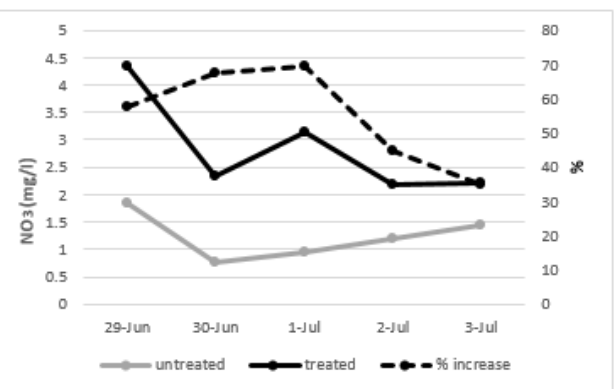

(d)

Figure 5: The concentration and removal efficiencies of (a) $\mathrm{Mg}$; (b) $\mathrm{SO}_{4}{ }^{2-}$; (c) $\mathrm{NO}_{3}$; and (d) $\mathrm{pH}$ in untreated and treated $\mathrm{AG}$. 
Usually the efficiency of greywater treatment system is assessed by their removal efficiencies of chemical and microbial contaminants that are of environmental and health concerns, and whether the treated greywater's quality is in compliance with local and/or international standards. The multimedia filter used in this study proved to be efficient in treating AG produced at MEC mosque. Despite being decreased (TSS, turbidity, $\mathrm{K}, \mathrm{BOD}_{5}$, $\mathrm{Na}$, and $\mathrm{Cl}$ ) or increased $\left(\mathrm{SO}_{4}{ }^{-2}, \mathrm{NO}_{3}\right.$, and $\mathrm{Mg}$ ) or fluctuated (Ca and TDS), the concentration of chemical contaminants in treated AG remained far below the acceptable limits set by Omani standards for reusing wastewater. However, the $\mathrm{pH}$ slightly exceeded the permissible limit and, therefore needs to be adjusted before reusing the treated water for irrigation and toilet flushing purposes.

\subsection{Cost of treatment unit}

The capital cost and operation and maintenance cost of the treatment system are presented in Table 3. The total cost of setting up the designed filter is 309 OMR (approximately 803 USD) which is much less than the commercially available greywater treatment systems, as the approximate cost of treatment system with similar capacity $\left(3 \mathrm{~m}^{3} / \mathrm{d}\right)$ is 9000 USD [9]. Whereas the O\&M cost of the system is 80 OMR (approximately 208 USD). The reason behind the low cost is the way the treatment system is designed and constructed. The treatment system is specifically designed for the AG at MEC mosque, targeting the quality and quantity of AG produced. Moreover, the use of locally available materials such as sand, activated carbon and water storage tanks further reduced the cost of treatment system.

Table 3: Capital, operational and maintenance cost of treatment unit.

\begin{tabular}{|l|c|}
\hline Items & Estimated cost (OMR) \\
\hline Capital cost & 120 \\
\hline Fabrication of filter, plumbing and labour & 45 \\
\hline Filter material & 64 \\
\hline Two water pump & 80 \\
\hline Two water storage tank & 309 \\
\hline \multicolumn{2}{|l|}{ Total capital cost } \\
\hline Operational and maintenance cost & 20 \\
\hline Electricity per year & 60 \\
\hline Maintenance per year & 80 \\
\hline Total O\&M cost &
\end{tabular}

\subsection{Water savings and financial benefits}

Usually the amount of water saving resulted by using a greywater treatment system are not equal to the amount of greywater collected or treated, rather they are equal to the amount of water savings achieved by the user [19]. However, this study intends to use the treated greywater for toilet flushing and irrigation at MEC College where more than 5000 student study, hence huge amount of water goes into toilet flushing. Therefore, this study calculates the water savings as the amount of greywater treated, because it is assumed as per the observation that treated greywater produced will be completely reused daily.

The quantity of AG generated at the MEC mosque was estimated by monitoring the quantity of water used by per person per ablution and the number of worshippers per week [4]. The average quantity of water required by a person for performing a single ablution was 
found to be 6 litres by monitoring a number of worshippers at the mosque at several prayer times in a day. Based on the information obtained from the survey, the AG produced for the whole month is estimated as:

Number of worshippers per week $\times 4$ weeks $\times$ volume of ablution water used by per person $=(2625 \mathrm{persons} /$ week $) \times(4$ weeks $) \times(6$ litres $/$ person $)$

$=63,000$ litres $/$ month $=63 \mathrm{~m}^{3} /$ month

$=16642.8$ gallons $/$ month

The financial benefit for the designed filter is calculated as follows [19]:

(Volume of water saving $\times$ Volumetric water rate) - O\&M cost/year

$=[(16642.8 \times 12) \times(0.003)]-80$

$=519.14 \mathrm{OMR} /$ year

*According to Public Authority of Electricity and Water, the price for one gallon of water in Oman is 0.003 baisa.

Therefore, it can be seen that the designed treatment system for MEC mosque can save $63 \mathrm{~m}^{3}$ of water per month and can also provide financial benefit by saving 519.14 OMR (approximately 1348.48 USD) yearly. Recycling AG at each mosque can bring immense long-term water conservation benefits and cost savings, especially when the freshwater reserves are depleting.

\section{CONCLUSION}

Ablution greywater (AG) being less contaminated provides an alternative source of water for irrigation and toilet flushing purposes. Results show that the quality of $\mathrm{AG}$ in terms of $\mathrm{pH}$, $\mathrm{BOD}_{5}, \mathrm{TDS}, \mathrm{NO}_{3}, \mathrm{Cl}, \mathrm{Na}, \mathrm{Mg}, \mathrm{K}, \mathrm{Ca}, \mathrm{SO}_{4}^{-2}$, and E. coli was acceptable for reuse as per the Omani standards, however the TSS and turbidity exceeded the permissible limits. After comparing the quality of AG with the past studies in Oman, this study concluded that the characteristics of AG significantly change with time and, therefore it is necessary to continuously monitor the quality of greywater and update treatment systems with time. The designed treatment system was effective in treating AG in Oman for irrigation and toilet flushing purposes. The concentration of chemical contaminants in treated AG remained far below the acceptable limits set by Omani standards for reuse of wastewater. However, the $\mathrm{pH}$ slightly exceeded the permissible limit and, therefore needs to be adjusted before reusing the treated water for irrigation and toilet flushing purposes. Furthermore, as per WHO guidelines, treated AG quality in this study is suitable for irrigation of fruit trees, fodder crops, and ornamentals. Lastly, this study concluded that the designed treatment system could save $63 \mathrm{~m}^{3}$ of water monthly at MEC mosque, and can provide a yearly financial benefit of 519.14 OMR (approximately 1348.48 USD).

\section{ACKNOWLEDGEMENT}

The authors are acknowledging the financial support given by The Research Council (TRC) Oman under the Open Research Grant (ORG) Program to conduct this research.

\section{REFERENCES}

[1] Ahmed, M., Prathapar, S. \& Al-Abri, A., Guidelines for reuse of greywater in Oman: A proposal. Second Oman-Japan Joint Symposium: Preservation of Environmental and Water Resources amid Economic Development, Muscat, Oman, pp. 75-79, 2005. 
[2] Noutsopoulos, C. et al., Greywater characterization and loadings: Physicochemical treatment to promote onsite reuse. Journal of Environmental Management, 216, pp. 337-346, 2018.

[3] Alharbi, S., Shafiquzzaman, M., Haider, H., AlSaleem, S. \& Ghumman, A., Treatment of ablution greywater for recycling by alum coagulation and activated carbon adsorption. Arabian Journal for Science and Engineering, 2019.

[4] Suratkon, A., Chan, C. \& Ab Rahman, T., SmartWUDHU': Recycling ablution water for sustainable living in Malaysia. Journal of Sustainable Development, 7(6), pp. 150157, 2014.

[5] Radin Mohamed, R., Adnan, M., Mohamed, M. \& Mohd Kassim, A., Conventional water filter (sand and gravel) for ablution water treatment, reuse potential, and its water savings. Journal of Sustainable Development, 9(1), p. 35, 2016.

[6] Al-Wabel, M., Simple system for handling and reuse of graywater resulted from ablution in mosques of Riyadh City, Saudi Arabia. International Conference on Environment Science and Engineering, Singapore, pp. 42-45, 2011.

[7] Abu-Rizaiza, O., Ablution water: Prospects for reuse in flushing of toilets at mosques, schools, and offices in Saudi Arabia. Journal of King Abdulaziz UniversityEngineering Sciences, 14(2), pp. 3-28, 2002.

[8] Al Mamun, A., Muyibi, S. \& Abdul Razak, N., Treatment of used ablution water from IIUM Masjid for reuse. Advances in Environmental Biology, 8(30), pp. 558-564, 2014.

[9] Prathapar, S., Ahmed, M., Al Adawi, S. \& Al Sidiari, S., Design, construction and evaluation of an ablution water treatment unit in Oman: A case study. International Journal of Environmental Studies, 63(3), pp. 283-292, 2006.

[10] Al-Zu'bi, Y., Ammari, T., Al-Balawneh, A., Al-Dabbas, M., Ta'any, R. \& Abu-Harb, R., Ablution greywater treatment with the modified re-circulated vertical flow bioreactor for landscape irrigation. Desalination and Water Treatment, 54(1), pp. 59$68,2015$.

[11] Jeong, H., Kim, H. \& Jang, T., Irrigation water quality standards for indirect wastewater reuse in agriculture: A contribution toward sustainable wastewater reuse in South Korea. Water, 8(4), pp. 169, 2016.

[12] Prathapar, S., Ahmed, M., Al-Adawi, S. \& Al-Sidiari, S., Variation in quality and quantity of greywater produced at two mosques in Oman. International Wastewater Conference, Salalah, Oman, 2004.

[13] Al Barwani, A. \& Helmi, T., Sea water intrusion in a coastal aquifer: A case study for the area between Seeb and Suwaiq, Sultanate of Oman. Agricultural and Marine Sciences, 11, pp. 55-69, 2006.

[14] Prathapar, S., Jamrah, A., Ahmed, M., Al Adawi, S., Al Sidairi, S. \& Al Harassi, A., Overcoming constraints in treated greywater reuse in Oman. Desalination, 186(1-3), pp. 177-186, 2005.

[15] Duqm, Water quality protection technical note. Duqm, 2018.

[16] Brown, C., Activated carbon | pureflow, Pureflow. https://www.pureflowinc.com/activated-carbon/. Accessed on: 11 Jun. 2019.

[17] Fosso-Kankeu, E., Heever, C., Gericke, G., Lemmer, N. \& Waanders, F., Evaluation of the performance of an activated carbon supplemented sand filter for the reduction of COD in brewery wastewater. 9th International Conference on Advances in Science, Engineering, Technology and Waste Management, 2017.

[18] Mallongi, A. et al., Clean water treatment technology with an up-flow slow sand filtration system from a well water source in the Tallo district of Makassar. Journal of Environmental Science and Technology, 10(1), pp. 44-48, 2016. 
[19] Gauley, B., Water savings and financial benefits of single-family package greywater systems. Alliance for Water Efficiency, Chicago, Illinois, 2017. 